\title{
Pollinator guild organization and its consequences for reproduction in three synchronopatric species of Tibouchina (Melastomataceae)
}

\author{
Ana Maria Franco ${ }^{1}$, Renato Goldenberg ${ }^{2} \&$ Isabela Galarda Varassin ${ }^{2,3}$
}

'Pós-Graduação em Ecologia e Conservação, Universidade Federal do Paraná, Caixa Postal 19031, 81531-980 Curitiba-PR, Brasil. francoanamaria@yahoo.com.br

${ }^{2}$ Departamento de Botânica, Centro Politécnico, Universidade Federal do Paraná, Caixa Postal 19031, 81531-980 Curitiba-PR, Brasil. renato.goldenberg@gmail.com; isagalarda@gmail.com

${ }^{3}$ Corresponding author.

\begin{abstract}
Pollinator guild organization and its consequences for reproduction in three synchronopatric species of Tibouchina (Melastomataceae). In co-flowering plant species, pollinator sharing can result in interspecific pollen transfer and fecundity reduction. Competition will be relaxed whenever there is a large amount of initial pollen supply or if each plant species occupies different habitat patches. Reproduction in Tibouchina cerastifolia (Naudin) Cogn., T. clinopodifolia (DC.) Cogn. and T. gracilis (Bonp1.) Cogn. was studied in an area of Atlantic rainforest to examine whether synchronopatry induces time partitioning among pollinator species. Eleven bee species comprised the pollinator guild. Among pollinators, there were overlaps in bee species composition and in flower visitation time. Direct competition for pollen in Tibouchina Aubl. at the study site seems to lead to different activity periods among the bee species, in which Bombus pauloensis Friese, 1913 was most active earlier, while the other species were active later in the day. Bombus pauloensis, the largest bee species recorded on Tibouchina flowers, was the most important and efficient pollinator. This species harvested pollen before the other species and had the shortest handling time. The plants reproduced sexually by selfing or outcrossing, and hybridization was not avoided by incompatibility reactions at the style. The avoidance of direct competition for pollen and no pollinator partitioning among the synchronopatric species of Tibouchina may reflect a facilitative interaction among these pioneer plants.
\end{abstract}

KEYWORDS. Bees, breeding systems; pollination; time partitioning.

RESUMO. Organização da guilda de polinizadores e sua consequência para reprodução em três espécies sincropátricas de Tibouchina (Melastomataceae). Em espécies de plantas que co-florescem, a partilha de polinizadores pode resultar em transferência interespecífica de pólen e redução da fecundidade. A competição pode ser relaxada quando existe uma grande quantidade de suprimento de pólen ou se cada planta ocupa manchas distintas do hábitat. A reprodução de Tibouchina cerastifolia (Naudin) Cogn., T. clinopodifolia (DC.) Cogn. e T. gracilis (Bonpl.) Cogn. foi estudada em Floresta Atlântica para verificar se a sincronopatria levava à partilha temporal das espécies de polinizadores. Onze espécies de abelhas compuseram a guilda de polinizadores. Entre eles, houve sobreposição na composição de espécies de polinizadores e no período de visitação floral. A competição direta por pólen em Tibouchina Aubl. na área de estudo parece levar a distintos períodos de atividade entre as abelhas, onde Bombus pauloensis Friese,1913 foi mais ativa mais cedo enquanto que as outras espécies foram ativas mais tarde. Bombus pauloensis, a maior espécie de abelha registrada em nas flores de Tibouchina, foi o polinizador mais importante e eficiente. Esta espécie coletava pólen antes das outras abelhas e apresentou um menor tempo de manipulação das anteras. As plantas se reproduziram sexuadamente, por autogamia e xenogamia e a hibridação não foi inibida por reações de incompatibilidade no estilete. A ausência de competição direta por pólen e de partilha de polinizadores pode refletir uma interação de facilitação entre estas três espécies pioneiras e sincronopátricas de Tibouchina.

PALAVRAS-CHAVE. Abelhas; polinização; sistemas reprodutivos; partilha temporal.

Plants that share pollinators may often have problem avoiding pollen loss and avoiding hybridization (Marques et al. 2007). This is most likely to occur if several species of pollinators use the same resources in closely related plant species. In co-flowering plant species, pollinator sharing can result in interspecific pollen transfer and fecundity reduction (Waser 1978a; Brown et al. 2002). The reduction of fecundity may act as a selective force that keeps flowering displacement in sympatric species (Waser 1978a). In synchronopatric species, competition will be relaxed and coexistence will occur whenever there is a large amount of initial pollen supply or if each plant species occupies differ- ent habitat patches (Waser 1978b). Besides that, the foraging area of pollinators may influence the effect of interspecific pollen transfer on the competition output (Waser 1978b).

Pollination quality is influenced by the mating system. In the family Melastomataceae most species are xenogamous due to herkogamy (i.e., stamens spatially distant from the stigma, Renner 1989). Self-incompatibility and apomixis are apparently common in the family, but not in the tribe Melastomeae and its genus Tibouchina Aubl., in which bees are the most important pollinators (Renner 1989; Goldenberg \& Shepherd 1998; Goldenberg \& Varassin 2001; Fracasso \& Sazima 2004). Important Neotropical pollinators for Melasto- 
mataceae include the bee genera Xylocopa Latreille, 1802, Melipona Illiger, 1806 and Augochloropsis Cockerell, 1897 (Renner 1989). Pollen loss due to pollen collection by many unspecialized animals is avoided in Melastomataceae because most species have poricidal anthers (Renner 1989), and also have only pollen as resource for pollinators. These species require that pollinators actively extract pollen (Buchmann 1983) and some bees do that through vibration of their flight muscles in a "buzz-pollination" behavior (Buchmann 1983; Renner, 1986/1987, 1990).

Flowering synchrony among sympatric species of plants (synchronopatry) may cause interspecific pollen transfer. This pollen transfer can result in a mere pollen loss or can cause hybridization (Marques et al. 2007). In some cases, interspecific pollen transfer (and pollen loss) can be minimized by different plant species releasing pollen at different times of the day (Stone et al. 1998; Wendt et al. 2002), by differences in the pollinator guilds among the synchronopatric species (Raine et al. 2007), or by pollinator specificity and flower constancy of shared pollinators (Marques et al. 2007). Alternatively, facilitative interaction among co-flowering plant species may occur (Moeller 2004; Ghazoul 2006). Flowering synchrony may enhance the diversity and/or the abundance of shared pollinators resulting in higher reproductive success.

The species Tibouchina cerastifolia (Naudin) Cogn., $T$. clinopodifolia (DC.) Cogn. and T. gracilis (Bonpl.) Cogn. (Melastomataceae) are herbs occurring in the same area. Their flowers can be categorized as pollen-flowers, since the only resource available to pollinators is pollen. They have overlapping flowering periods and are visited by several bee species. Since plant populations from these three species were dense and co-occurring, bees explore any cluster of plants composed by more than one species they eventually encounter, including other Melastomataceae. In this situation, these visits are also likely to result in interespecific pollinations. We examined the organization of this "pollinator guild" to understand whether synchronopatry may induce pollinator partitioning to avoid pollinator competition or hybridization. Specifically, our goals were to (1) determine the composition of the guild of pollinators (2) test for temporal or behavioral differences in flower resource use by different pollinators visiting the same plant species (3) test the breeding system of the species, their dependence on pollinators and the possibility of hybridization in controlled interspecific pollinations".

\section{MATERIAL AND METHODS}

Study site. Tibouchina and pollinating bees were studied in a private reserve in the municipality of Piraquara, Paraná State, in February - April in 2004 and 2005 and January April 2006. This forested area is a transition between subtropical Araucaria forest and Tropical Atlantic rainforest (Reginato \& Goldenberg 2007). The climate is subtropical moist mesothermic, "Cbf" following Koeppen (McKnight \& Hess 2005), with a mild summer, frosts in winter and without a dry season. The mean temperature in the warmer months is $<22^{\circ} \mathrm{C}$ and in the cooler months $<18^{\circ} \mathrm{C}$. Rainfall varies from 1,300-1,500 $\mathrm{mm} \mathrm{yr}^{-1}$ (SPVS 1996). The observations were at $25^{\circ} 20^{\prime} 37^{\prime} \mathrm{S}, 48^{\circ} 59^{\prime} 38^{\prime \prime} \mathrm{W}, 981 \mathrm{~m}$, and at $25^{\circ} 29^{\prime} 47^{\prime} \mathrm{S}$, $48^{\circ} 58^{\prime} 53^{\prime \prime} \mathrm{W}, 1013 \mathrm{~m}$.

Focal species. Tibouchina cerastifolia, T. clinopodifolia and $T$. gracilis are xylopodiferous herbs, $10-50 \mathrm{~cm}$ tall. Tibouchina cerastifolia and T. gracilis occur in sparse or dense populations at places with high sunlight incidence, while $T$. clinopodifolia is usually found in smaller numbers in relatively shaded places. The studied plants were in clear patches at the forest edge, mostly along roads and trails, and were exposed to direct sunlight at least during part of the day.

Tibouchina cerastifolia and T. clinopodifolia flowering lasted from January to April and in T. gracilis from the end of December to the beginning of March. Thus, they are clearly synchronopatric.

Flowers last one (T. cerastifolia, T. gracilis) or two days (T. clinopodifolia). Flowers of T. cerastifolia are $20-25 \mathrm{~mm}$ wide, with hypanthia varying from green to red and pink petals. The anthers from the antipetalous cycle are yellow, while the ones from the antisepalous cycle are reddish, yellow or white connective Fig. 1A, 1B). Flowers of $T$. clinopodifolia are 5-10 mm wide, with green hypanthia, light purple petals, yellow anthers and greenish-yellow connective (Fig. 1C). The flowers of T. gracilis are 30-40 mm wide, with green hypanthia, pink petals, yellow anthers and reddish connective Fig. 1D).

Flower visitors. Flower visitors were observed during six hour sessions, between 08:00-14:00 h. The focal observations (sensu Dafni 1992) were spread on different individuals and days, so nine plants of Tibouchina cerastifolia were observed during 180 hours, six plants of T. clinopodifolia were observed during 180 hours and nine plants of T. gracilis were observed during 144 hours. The methods of pollen harvesting by flower visitors were categorized in (1) chewing by pollen robbers, when the bees cut parts of the anthers, or (2) sonication, when the bees did vibrate the anthers (Buchmann 1983). The bee visits per flower were counted during the whole focal observation session and grouped in 30 min of observation intervals to calculate the average bee visits per flower per $30 \mathrm{~min}$. Mean number of bee visits per flower per day was calculated by the average bee visits per flower per $30 \mathrm{~min}$. A visit was considered the first foraging bout to a plant. To test the differences in the patterns of forager's activity through time, the relationship between the number of visits and day time was tested by linear regression analysis. Only bees with more than 20 observations were considered. For all the analysis, the numbers of bee visits were $\log$ transformed.

The handling time was defined as the interval starting when the bee began chewing or vibrating and ending when the bee stopped those activities. A single visit may result in many handling times, since a bee can visit many flowers of a plant when foraging. The measure of anthers handling time by bees was used as an estimator of differences in pollinator behavior and was measured because it may be associated with 

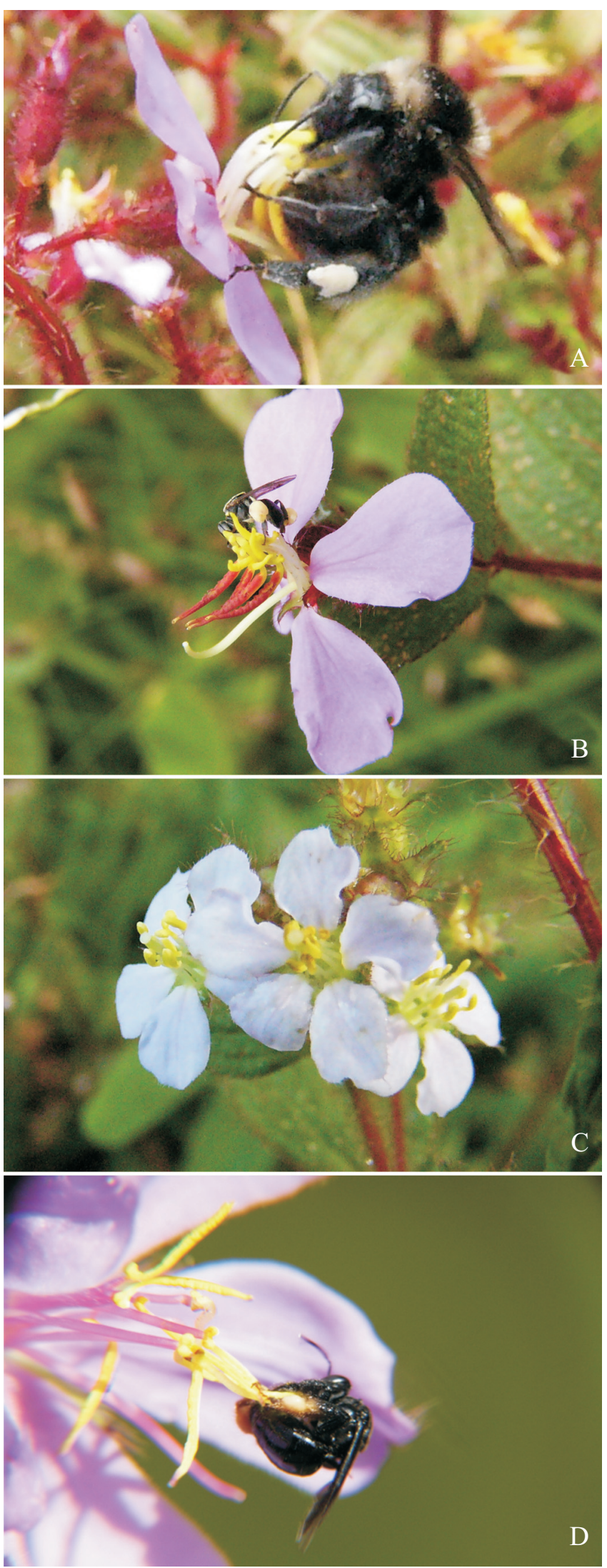

Fig. 1 Flowers and bee visitors of Tibouchina A, Bombus pauloensis, buzzpollinating a flower of T. cerastifolia; B, Paratrigona subnuda, a pollen thief, on a flower of T. cerastifolia; C, Flowers of T. clinopodifolia; D, Trigonopedia sp. handling few stamens on T. gracilis. pollen availability in the anthers (Buchmann \& Cane 1989). To test if there was a reduction in handling time during flower anthesis, the mean handling time of the most frequent bee species was calculated and compared by ANOVA in each plant species. The means at each 30-min interval were compared using the Tukey test.

The pollinator efficiency was estimated by counting the number of fruit formed per flower pollinated after a single pollinator visit. Flowers were bagged in pre-anthesis. During the experiment, the flowers were uncovered, and then again bagged after a single pollinator visit. After one month, for each pollinating species, the number of fruit formed per flower per visit was counted. The numbers for either fruit formation (success) or fruit abortion (failure) were used to estimate the efficiency of each pollinator species; differences between pollinators were tested using Chi-square analysis. Since this experiment was determined by the visits of the pollinators, it was impossible to assure equal sample size among the pollinating species. For the same reason, only the most frequent pollinators were considered.

Breeding systems. Five treatments were used to determine plant mating system: 1) open (uncontrolled) pollination, where the flowers were only marked on the pedicel; 2) agamospermy, where the buds were emasculated and bagged; 3) autonomous self-pollination, where the buds were bagged; 4) self-pollination, where pollen was manually transferred from anthers to the stigma of the same flower and 5) crosspollination, where pollen was manually transferred from anthers from one individual to the stigma of another individual (Radford et al. 1974). All treatments were performed between 9 and 12 a.m., with at least 30 flowers in each treatment for each species. Since each individual produces a little amount of flowers and up to three flowers a day, many plants were used in those treatments so at least seven individuals per treatment and maximum of 17 individuals per treatment were used. Anthesis lasted two days for T. clinopodifolia, but pollinations were performed only on first-day flowers. The fruit development was followed until ripening, for about a month. Reproductive success was estimated by the number of fruits formed per treatment.

To examine the occurrence of self-incompatibility reaction, observations were done using flowers from crossing and selfing treatments. Three flowers in each treatment were examined 24 and 48 hours after pollination. Flowers were first fixed in FAA and then placed for clearing in $\mathrm{NaOH} 6 \mathrm{M}$ solution at $60^{\circ} \mathrm{C}$ for $40 \mathrm{~min}$., then stained with aniline blue and subsequently viewed under fluorescence microscopy (Martin 1959). The non-occurrence of pollen germination indicates sporophytic incompatibility, while pollen-tube growth cessation and calosis deposition at the pollen-tube apex indicates gametophytic incompatibility (after Richards 1997).

Fruit-set was compared between pollination treatments using the $G$ test. The Index of Self-Incompatibility (ISI, sensu Bullock 1985) was calculated as the fruit-set ratio between self and cross pollination. We also calculated the Reproductive Efficacy Index (RE; Zapata \& Arroyo 1978; Oliveira \& 
Gibbs 2000), which is the ratio between fruit-set from open pollination and fruit-set from crossing. Interspecific cross pollinations were used to test for hybridization between all pair wise combinations with each of the three species as pollen donor for the other two species. Pollinations were done using the pollen directly from the anther on the other species to be sure that pollen deposition was heterospecific. All crossings comprised four flowers of each combination that were then examined $24 \mathrm{~h}$ ( 2 flowers) and $48 \mathrm{~h}$ ( 2 flowers) after pollination. Pollen-tube growth was analyzed under fluorescence microscopy as described above.

\section{RESULTS}

Flower visitors. Eleven bee species from nine genera visited the flowers of Tibouchina. Bombus pauloensis (Fig. 1A) and Melipona marginata were the most frequent at flowers of all species, in number of visits per flower per day, although $M$. marginata did few visits in T. clinopodifolia. Other bees were only sporadic flower visitors on T. cerastifolia and T. clinopodifolia ( $\leqslant 0.4$ visits per flower per day), while in Tibouchina gracilis there were much more visits than to the other two plant species (Table I). Nine, six and five bee species visited $T$. cerastifolia, $T$. gracilis and T. clinopodifolia, respectively (Table I). Tibouchina cerastifolia was also pollinated by Augochloropsis sp. 2, Euglossa mandibularis, Melipona bicolor, Trichocerapis mirabilis and Xylocopa artifex. Tibouchina clinopodifolia was also pollinated by Augochloropsis sp. 1, Augochloropsis sp. 2 and Trigonopedia sp. Tibouchina gracilis was also pollinated by Augochloropsis sp. 1, Augochloropsis sp. 2, Trigonopedia sp. and Xylocopa artifex.

Bombus pauloensis began the visits earlier than the other bee species, just at the beginning of anthesis in $T$. clinopodifolia and T. gracilis (Fig 2). In T. cerastifolia, B. pauloensis was the most frequent visitor at the beginning of anthesis, but it shared the flowers with two other bee species, Melipona bicolor and M. marginata. Bombus pauloensis was already at its peak of activity when observations began at 08:00 or 08:30, followed by declining visit rates (Fig. 2). As the visit rate of that species declined, the other species increased or remained constant (Fig. 2). In T. cerastifolia, the visits of $B$. pauloensis decreased during anthesis $\left(\mathrm{r}^{2}=\right.$ $\left.0.37 ; \mathrm{F}_{1,21}=13.70 ; \mathrm{p}=0.0013\right)$. The number of visits of $M$. marginata did not change along the anthesis $\left(\mathrm{r}^{2}=0.11 ; \mathrm{F}_{1,9}=\right.$ 2.30; $\mathrm{p}>0.05$. In $T$ clinopodifolia, the regression analyses were not performed since the residuals of the number of visits of Bombus pauloensis were not normalized. In T. gracilis, the frequency of Bombus pauloensis decreased during anthesis $\left(\mathrm{r}^{2}=0.15 ; \mathrm{F}_{1,37}=7.72 ; \mathrm{p}=0.0085\right)$. The visit numbers of $M$. marginata and Trigonopedia sp. were constant during anthesis $\left(r^{2}=0.08 ; \mathrm{F}_{1,30}=3.73 ; \mathrm{p}>0.05\right.$ and $\mathrm{r}^{2}=0.03, \mathrm{~F}_{1,30}=$ $0.003 ; \mathrm{p}>0.05$, respectively). For Augochloropsis sp. 1 and Augochloropsis sp. 2, the regression analyses were not performed since the residuals were not normalized. Handling time by some bees was longest at the beginning of anthesis (Fig. 3), when resources are likely to be more abundant. Nonetheless, some species increased handling time in each flower at the end of anthesis (Fig. 3). Handling time in $B$. pauloensis was longer at the very beginning and the end of anthesis in T. cerastifolia $\left(\mathrm{F}_{6,580}=8.47\right.$; Tukey test $\mathrm{q}=2.95 ; \mathrm{p}$ $<0.0001$, Fig. 3A), and at the beginning of the anthesis of $T$. gracilis $\left(\mathrm{F}_{7,1796}=16.71\right.$; Tukey test $\mathrm{q}=3.03 ; \mathrm{p}<0.0001$, Fig. 3B), while handling time in $T$. clinopodifolia was constant $\left(\mathrm{F}_{7,301}=1.40 ; \mathrm{p}=0.2038\right)$. The first visits in the morning were usually longer, approximately 90 seconds, and subsequent visits were shorter, lasting 1-2 seconds each, for all three species of Tibouchina. Handling time of M. marginata in $T$. cerastifolia tended to be longer after $10: 30 \mathrm{~h}\left(\mathrm{~F}_{6,155}=\right.$ 3.57; Tukey test $q=2.99 ; \mathrm{p}=0.0024$; Fig. 3A) but in T. gracilis it was longer early in anthesis $\left(\mathrm{F}_{11,635}=6.31\right.$; Tukey test $\mathrm{q}=3.28 ; \mathrm{p}<0.0001 ;$ Fig. 3B). Other bees were frequent

Table I. Mean number of bee visits per flower per day in three species of Tibouchina and the methods of pollen harvesting by the flower visitors in three species of Tibouchina. $\mathrm{c}$ - chewing and $\mathrm{s}-$ sonication.

\begin{tabular}{|c|c|c|c|c|}
\hline \multirow{2}{*}{ Bees } & \multicolumn{3}{|c|}{ Mean number of visits per day } & \multirow{2}{*}{$\begin{array}{c}\text { Pollen harvesting } \\
\text { method }\end{array}$} \\
\hline & T. cerastifolia & T. clinopodifolia & T. gracilis & \\
\hline \multicolumn{5}{|l|}{ Apinae } \\
\hline Bombus pauloensis Friese, 1913 & 1.96 & 1.23 & 5.50 & $\mathrm{~s}$ \\
\hline Euglossa mandibularis Friese, 1899 & 0.03 & - & - & s \\
\hline Melipona bicolor Lepeletier, 1836 & 0.40 & - & - & s \\
\hline Melipona marginata Lepeletier, 1836 & 0.93 & 0.10 & 3.04 & s \\
\hline Paratrigona subnuda Moure, 1947 & 0.16 & - & - & $\mathrm{c}$ \\
\hline Rhophitulus sp. & 0.16 & - & - & $\mathrm{c}$ \\
\hline Trichocerapis mirabilis (Smith, 1865) & 0.03 & - & - & s \\
\hline Trigonopedia $\mathrm{sp}$ & - & 0.23 & 2.28 & s \\
\hline Xylocopa artifex Smith, 1874 & 0.03 & - & 0.12 & s \\
\hline \multicolumn{5}{|l|}{ Halictinae } \\
\hline Augochloropsis sp. 1 & - & 0.3 & 1.12 & $\mathrm{~s}$ \\
\hline Augochloropsis sp. 2 & 0.03 & 0.1 & 1.08 & s \\
\hline
\end{tabular}



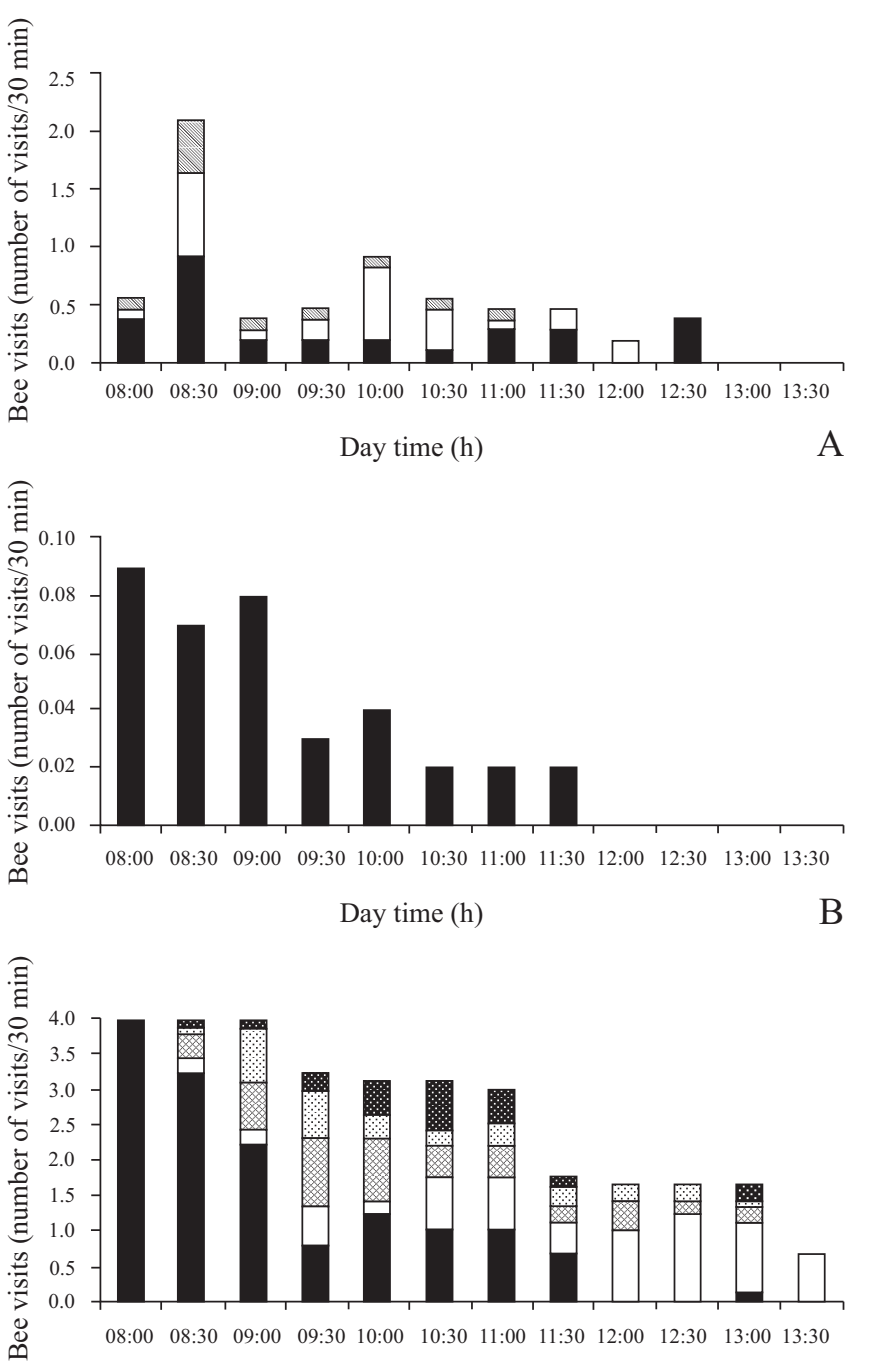

Day time (h)

\section{$\mathrm{C}$}

Fig. 2 Mean number of bee visits at each class of half hour in flowers. A, $T$. cerastifolia (330 minutes of observation for each class); B, T. clinopodifolia (300 minutes of observation for each class); C, T. gracilis (270 minutes of observation for each class). Note the different scales. Bars: Bombus pauloensis (black), Melipona marginata (white), Melipona bicolor (diagonals), Trigonopedia sp. (lozenges), Augochloropsis sp. 1 (black dots in a white background), Augochloropsis sp. 2 (white dots in a black background). Only bees with more than 10 observations were plotted.

visitors to T. gracilis (Table I) and their handling time differed. That is the case of Augochloropsis sp. 1, in which handling time was longer between 10:00-10:30 h $\left(\mathrm{F}_{9,231}=2.28\right.$; Tukey test $\mathrm{q}=3.19 ; \mathrm{p}<0.0183$; Fig. 3B) and in Trigonopedia sp., whose handling time was longer before 10:00 $\mathrm{h}\left(\mathrm{F}_{8,480}=\right.$ 5.65; Tukey test $\mathrm{q}=3.12$; $\mathrm{p}<0.0001$; Fig. 3B).

Bombus pauloensis was an efficient pollinator for all three species of Tibouchina, with pollination efficiency after a single visit varying from 68 to $93 \%$ (Table II). Melipona marginata and Trigonopedia sp. were also efficient, with some variation among species (Table II). Pollination efficiency was different among the bees Augochloropsis sp.2, B. pauloensis and $M$. marginata on T. clinopodifolia $\left(\chi^{2}{ }_{59}=\right.$
18.74; $\mathrm{p}<0.0001)$ and among $B$. pauloensis, M. marginata and Trigonopedia sp. on T. gracilis $\left(\chi_{123}^{2}=16.60 ; \mathrm{p}=0.0002\right.$; Table II). In T. cerastifolia the only visitor tested for efficiency was B. pauloensis (Table II).
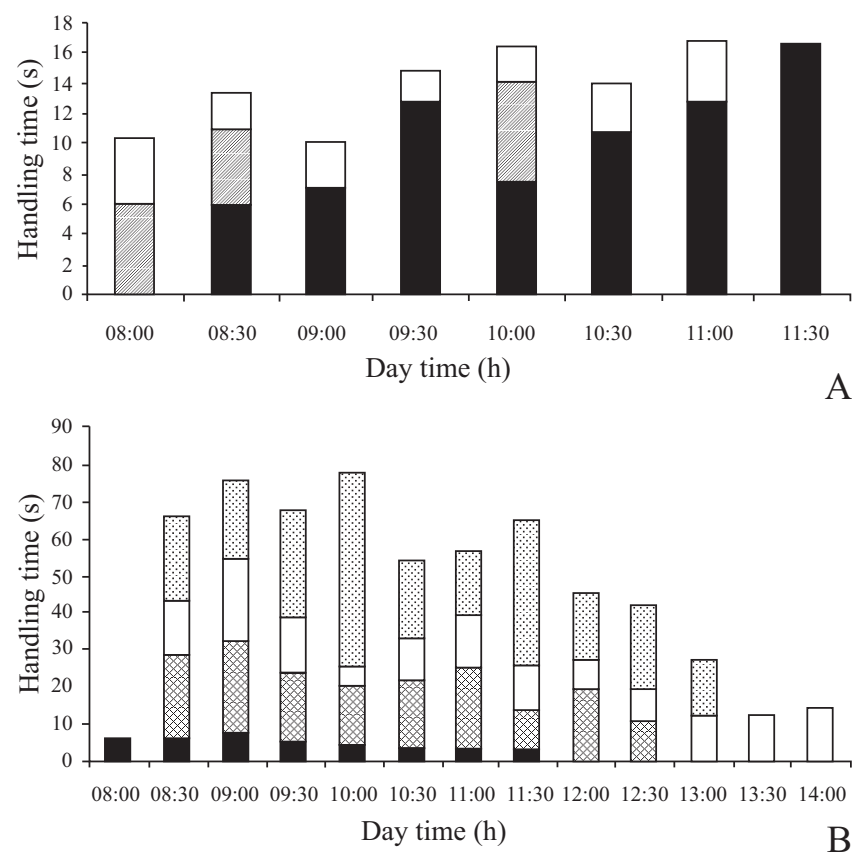

Fig. 3 Mean handling time of each bee species at each class of half hour. A, at flowers of T. cerastifolia; B, at flowers of T. gracilis. Note the different scales. Bars: Bombus pauloensis (black), Melipona bicolor (diagonals), Melipona marginata (white), Augochloropsis sp. 1 (black dots in a white background), and Trigonopedia sp. (lozenges).

Table II. Pollinator efficiency estimated by percent fruit set (number of fruits/number of flowers) after one bee visit to Tibouchina cerastifolia. T. clinopodifolia and T. gracilis. - Not observed.

\begin{tabular}{lccc}
\hline \multirow{2}{*}{ Pollinator } & \multicolumn{3}{c}{ Fruit set,\% (Flower number) } \\
\cline { 2 - 4 } & T. cerastifolia & T. clinopodifolia & T. gracilis \\
\hline Augochloropsis sp. 1 & - & $46(13)$ & $20(5)$ \\
Augochloropsis sp. 2 & - & - & $0(8)$ \\
Bombus pauloensis & $68(66)$ & $93(42)$ & $93(44)$ \\
Melipona marginata & - & $100(9)$ & $60(53)$ \\
Trigonopedia sp. & - & $94(16)$ & $0(33)$ \\
\hline
\end{tabular}

Breeding systems. Agamospermy was not detected in any species (Table III). All three species set fruits after self-pollination and only T. gracilis did not set fruit in the autonomous pollination treatment. Compared to autonomous pollination, fruit set was always larger in self-pollination, cross pollination and open pollination tests. Fruit set was different between treatments in all species (Table III). Index of Self-Incompatibility and Reproductive Efficacy Index values were high for all species. Hence, the three species may be considered self-compatible with efficient natural pollination. 
Table III. Percent fruit set (sample size) in different controlled pollination treatments in three species of Tibouchina. ISI: Index of Self-Incompatibility (selfing/crossing fruit set); RE: Reproductive Efficacy Index (open pollination/crossing fruit-set).

\begin{tabular}{lccc}
\hline \multicolumn{1}{c}{ Treatment } & T. cerastifolia & T. clinopodifolia & T. gracilis \\
\hline Agamospermy & $0(71)$ & $0(14)$ & $0(32)$ \\
Autonomous pollination & $25(60)$ & $62(29)$ & $0(30)$ \\
Crossing & $67(46)$ & $97(30)$ & $89.7(39)$ \\
Selfing & $50(30)$ & $78(28)$ & $90.7(43)$ \\
Open pollination & $57(63)$ & $73(15)$ & $93.8(48)$ \\
ISI & 0.74 & 0.81 & 1.03 \\
RE & 0.84 & 0.87 & 1.04 \\
Chi-square tests & $\chi_{4}^{2}=90.9 ;$ & $\chi_{4}^{2}=49.9 ;$ & $\chi_{4}^{2}=180.2 ;$ \\
& $\mathrm{p}<0.0001$ & $\mathrm{p}<0.0001$ & $\mathrm{p}<0.0001$ \\
\hline
\end{tabular}

None of the three species showed SI reactions. The pollen grains germinated, and interruption of the pollen tube growth was not detected. Pollen-tubes were seen entering the ovules 24 hours after pollination in self- and cross-pollinated flowers from T. cerastifolia and T. clinopodifolia. In T. gracilis, pollen tubes were not seen entering the ovules due to the thick, dark tissue of the ovaries, although they were seen growing at a similar rate in the style of selfed self- and crosspollinated flowers.

Three interspecific crossings among the six performed resulted in pollen tube growth and may indicate hibridization. Ovule penetration was only seen in cross pollination among T. cerastifolia (pollen donor) and T. clinopodifolia. Ovary penetration was observed in crosses among T. clinopodifolia (pollen donor) and T. cerastifolia and among T. gracilis (pollen donor) and T. clinopodifolia. In cross-pollinations among T. clinopodifolia (pollen donor) and $T$. gracilis, only pollen germination was observed, but there was no pollen tube growth. In cross-pollinations among T. cerastifolia and $T$. gracilis (both as pollen donor and pollen receiver), no pollen grains were seen on the stigmas and then these experiments were uninformative.

\section{DISCUSSION}

There is no clear pollinator guild partitioning among Tibouchina cerastifolia, T. clinopodifolia and T. gracilis, since they share many pollinators. Our results suggest that the dynamics of flower visitation is due to biotic factors, mostly resource competition by bees. The strategies adopted by the bees to minimize the effects of direct competition for the pollen may include daily time partitioning, through the establishment of distinct activity peaks among bee species. In this case, the bee with the larger pollen-load capacity, $B$. pauloensis, is the one that initiates the visits. At least for T. cerastifolia and T. gracilis, B. pauloensis does most visits at the beginning of the anthesis. The remaining pollen, perhaps not abundant enough for B. pauloensis, can be collected in successive visits by smaller bees for which the remaining quantity of pollen is still profitable.
Bombus pauloensis is the most important pollinator for the three melastome species studied here. Since it is the first and earliest visitor to the flowers, it is likely to gather most of the pollen, while visits by the other species are spread throughout the rest of the day. Bees from the genus Bombus can assess the availability of pollen in the anthers by regulating sonication and handling time at each flower (Buchmann \& Cane 1989), and this can influence the number of visits and therefore its frequency at each inflorescence (Harder 1990). Buzzing time tends to be larger during the first visits, then it decreases at a rate that depends on the number of previous visits and, consequently, the amount of pollen left in the flowers (Kawai \& Kudo 2009).

Other bee species (M. bicolor in T. cerastifolia, $M$. marginata, Trigonopedia sp. and Augochloropsis sp. 1 in T. clinopodifolia) harvest pollen in lower quantities. They were more frequent during warmer and dryer hours and may have been influenced by the fact that pollen is more easily removed from poricidal anthers when it is drier and powdery (Corbet et al. 1988). The dehydration of the tapetum fluid in poricidal anthers, more precisely where pollen still remains after several visits, may favor a gradual release of this pollen along the day (King \& Buchmann 1996). The bees of T. gracilis visited the flowers at a fairly constant rate throughout the morning, except for B. pauloensis. Tibouchina gracilis has large flowers and anthers, at least when compared to the other species, and its populations were very dense in the area. Both can result in high resource availability, which in turn may affect the number of visits (Harder 1990).

Handling time in T. gracilis and T. cerastifolia flowers was related to bee size and was shorter for the larger (B. pauloensis) than for smaller bees (M. marginata, Trigonopedia sp., Augochloropsis sp. 1 and Augochloropsis sp. 2). This may be due to their vibration behavior, since smaller bees often collected from one anther at a time (Renner 1989; Fracasso \& Sazima 2004). Furthermore, visits may last longer because less pollen was available because flowers of $T$. gracilis were intensively visited by $B$. pauloensis early in the day. Thus, even though smaller bees have smaller pollen loads, handling time was still greater.

Single visits from B. pauloensis resulted in a high reproductive success. This is probably due to compatibility between bee and flower sizes, facilitating pollen deposition. Larger bees are more likely to contact the stigma while gathering pollen (Coleman \& Coleman 1982) and so are more effective than the smaller bees (Sahlo \& Conner 2007). However, smaller bees can pollinate smaller flowers efficiently, such as $T$. clinopodifolia, as well as larger flowers. For example, $M$. marginata and Trigonopedia sp. contacted the stigma of $T$. gracilis because they walk over the flower while searching for an anther at which to collect pollen. Since smaller bees are in front of the pore while vibrating, they may be more effective removing the pollen and so their efficiency in pollination may be strongly influenced by the behavior rather than size (Sahlo \& Conner 2007). On the other hand, since T. cerastifolia and $T$. clinopodifolia set fruit by autonomous pollination, part of the 
fruits formed in the pollinator efficiency experiments may be due to autonomous selfing. It is also possible that all fruits produced in the Augochloropsis sp.1 experiments in $T$. clinopodifolia are from autonomous selfing. However, if Tibouchina can set fruit by the occurrence of pseudogamy (Richards 1997), the results from the breeding experiments may be influenced by pseudogamy.

Fruit production from autonomous selfing treatments in $T$. clinopodifolia may be a consequence of the absence of herkogamy, in contrast to T. cerastifolia, in which herkogamy is marked. The absence of herkogamy is uncommon in Tibouchina, but low selfing rates are known in two other species of Tibouchina (Goldenberg \& Shepherd 1998; Goldenberg \& Varassin 2001). Tibouchina clinopodifolia has small flowers and stamens with large pores that are very close to the stigma, which may allow the anther to release pollen without vibration (Goldenberg et al. 2008). Pollen release by vigorous movements caused by wind or rain is known for poricidal anthers (Renner 1989 citing observations from F. Almeda). This may explain autonomous selfing in $T$. cerastifolia and $T$. clinopodifolia, since the plants are exposed to rain and wind.

Although T. cerastifolia, T. clinopodifolia and T. gracilis are self-compatible, reproductive success increased when flowers were visited by bees. Mixed mating may occur in these species, as in other Angiosperms (Vogler \& Kalisz 2001). Multiple visits to each flower during anthesis (i.e., not restricted to the first pollen removals) may favor xenogamy. On the other hand, the first visits may favor selfing through autogamy or geitonogamy (Kawai \& Kudo 2009). Both autonomous selfing and pollinator-mediated selfing, as in Tibouchina, allow plants to quickly occupy new spaces (Pannel \& Barrett 1998), and are ecologically advantageous for pioneer species (Wells 1979; Holsinger 2000). Yet, bee visits were apparently not a limiting factor to pollination in this study. For Tibouchina it is difficult to separate its ecological advantage from its phylogenetic constraints, since selfing is apparently a common feature in the tribe Melastomeae, to which this genus belongs (Goldenberg \& Shepherd 1998).

Pollinator sharing in species with flowering synchrony may result in larger fruit set (Gross et al. 2000). Such a response is expected from these bees because they are sensitive to resource density (Hegland \& Boeke 2006). As a consequence of pollinator sharing, these species may hybridize. The consequence of hybridization should be examined to better understand species isolation mechanisms, since genetic barriers were not detected but may still occur. Nevertheless, individuals with intermediate characters are common among the populations that were studied here, thus indicating that hybridization is not uncommon.

\section{ACKNOWLEDGMENTS}

We thank Eduardo L. Borba, Fernando Silveira, James J. Roper and Leandro Freitas, for comments on earlier versions of the manuscript, Antonio Luis Serbena for help during fieldwork, SANEPAR for the access to the area, Antonio J. C.
Aguiar and Gabriel A. R. de Melo for the identification of the bees. The present paper is part of MSc dissertation of the senior author. James J. Roper critically reviewed the manuscript and the English.

\section{REFERENCES}

Brown, B. J.; R. J. Mitchell \& S. A. Graham. 2002. Competition for pollination between an invasive species (purple loosestrife) and a native congener. Ecology 83: 2328-2336.

Buchmann, S. L. 1983. Buzz pollination in Angiosperms, p. 73-113. In: C. E. Jones \& R. J. Little (eds.). Handbook of experimental pollination biology. New York, Van Nostrand Reinhold, 588 p.

Buchmann, S. L. \& C. H. Cane. 1989. Bees assess pollen returns while sonicating Solanum flowers. Oecologia 81: 289-294.

Bullock, S. H. 1985. Breeding systems in the flora of a tropical dioecious forest. Biotropica 17: 287-301.

Coleman, J. R. \& M. A. Coleman. 1982. Reproductive biology of andromonoeciou Solanum (Solanum palinacanthum Dunal.). Biotropica 14: 55-87.

Corbet, S. A.; H. Chapman \& N. Saville. 1988. Vibratory pollen collection and flower form: bumble-bees on Actinidia, Symphytum, Borago and Polygonatum. Functional Ecology 2: 147-155.

Dafni, A. 1992. Pollination ecology: a pratical approach. New York, Oxford University Press, $250 \mathrm{p}$.

SPVS. 1996. Manual para recuperação da reserva florestal legal. Curitiba, FNMA, 67 p.

Fracasso, C. M. \& M. Sazima. 2004. Polinização de Cambessedesia hilariana (Kunth) DC. (Melastomataceae): sucesso reprodutivo versus diversidade, comportamento e freqüência de visitas de abelhas. Revista Brasileira de Botânica 27: 794-804.

Ghazoul, J. 2006. Floral diversity and the facilitation of pollination. Journal of Ecolgy 94: 295-304.

Goldenberg, R.; D. S. Penneys; F. Almeda; W. S. Judd \& F. A. Michelangeli. 2008. Phylogeny of Miconia (Melastomataceae): patterns of stamen diversification in a megadiverse neotropical genus. International Journal of Plant Sciences 169: 963-979.

Goldenberg, R. \& G. J. Shepherd. 1998. Studies on the reproductive biology of Melastomataceae in "cerrado" vegetation. Plant Systematics and Evolution 211: 13-29.

Goldenberg, R. \& I. G. Varassin. 2001. Sistemas reprodutivos de espécies de Melastomataceae da Serra do Japi, Jundiaí, São Paulo, Brasil. Revista Brasileira de Botânica 24: 283-288.

Gross, C.; L. Mackay \& M. A. Whalen. 2000. Aggregated flowering phenologies among three sympatric legumes. Plant Ecology 148: 1321.

Harder, L. D. 1990. Pollen removal by bumble bees and its implications for pollen dispersal. Ecology 71:1110-1125.

Hegland, S. J. \& L. Boeke. 2006. Relationships between the density and diversity of floral resources and flower visitor activity in a temperate grassland community. Ecological Entomology 31: 532-538.

Holsinger, K. E. 2000. Reproductive systems and evolution in vascular plants. Proceedings of the National Academy of Sciences 97: 7037-7042.

Kawai, Y. \& G. Kudo. 2009. Effectiveness of buzz pollination in Pedicularis chamissonis: signiûcance of multiple visits by bumblebees. Ecological Research 24: 215-223.

King, M. J. \& S. L. Buchmann. 1996. Sonication dispensing of pollen from Solanum laciniatum flowers. Functional Ecology 10: 449-456.

Marques, I.; A. Rossello-Graell; D. Draper \& J. M. Iriondo. 2007. Pollination patterns limit hybridization between two sympatric species of Narcissus (Amaryllidaceae). American Journal of Botany 94: 1352-1359.

Martin, F. N. 1959. Staining and observing pollen tubes in the style by means of fluorescence. Stain Technology 34: 125-128.

Mcknight, T. L. \& D. Hess. 2005. Physical geography: a landscape appreciation. Upper Saddle River, Prentice Hall, 640 p. 
Moeller, D. A. 2004. Facilitative interactions among plants via shared pollinators. Ecology 85: 3289-3301.

Oliveira, P. E. \& P. E. Gibbs. 2000. Reproductive biology of wood plants in a cerrado community of Central Brazil. Flora 195: 311-329.

Pannell, J. R. \& S. C. H. Barrett. 1998. Baker's law revisited: reproductive assurance in a metapopulation. Evolution 52: 657-668.

Radford, A. E.; W. C. Dickison; J. R. Massey; R. C. Bell \& M. S. Seiler. 1974. Vascular plant systematic. New York, Harper \& Row, 891 p.

Raine, N. E.; A. S. Pierson \& G. N. Stone. 2007. Plant-pollinator interactions in a Mexican Acacia community. Arthropod-Plant Interactions 1: 101-117.

Reginato, M. \& R. Goldenberg. 2007. Análise florística, estrutural e fitogeográfica da vegetação em região de transição entre as Florestas Ombrófilas Mista e Densa Montana, Piraquara, Paraná, Brasil. Hoehnea 34: 349-364.

Renner, S. S. 1986/1987. Reproductive biology of Bellucia (Melastomataceae). Acta Amazonica 16/17: 197-208.

Renner, S. S. 1989. A survey of reproductive biology in Neotropical Melastomataceae and Memecylaceae. Annals of the Missouri Botanical Garden 76: 469-518.

Renner, S. S. 1990. Reproduction an evolution in some genera of neotropical
Melastomataceae. Memoirs of the New York Botanical Garden 55: $143-152$.

Richards, A. J. 1997. Plant breeding systems. London, Chapman \& Hall, 529 p. Sahlo, H. F. \& J. K. Conner. 2007. Visitation, effectiveness, and efficiency of 15 genera of visitors to wild radish, Raphanus raphanistrum (Brassicaceae). American Journal of Botany 94: 203-209.

Stone, G.; P. G. Willmer \& J. A. Rowe. 1998. Partitioning of pollinators during ûowering in an African Acacia community. Ecology 79: 2808-2027.

Vogler, D. W. \& S. Kalisz. 2001. Sex among the flowers: the distribution of plant mating systems. Evolution 55: 202-204.

Waser, N. M. 1978a. Competition for hummingbird pollination and sequential flowering in Colorado wildflowers. Ecology 59: 934-944.

Waser, N. M. 1978b. Interspecific pollen transfer and competition between co-occurring plant species. Oecologia 36: 223-236.

Wells, H. 1979. Self-fertilization: advantageous or deleterious. Evolution 33: $255-352$.

Wendt, T.; M. B. F. Canela; D. E. Klein \& R. I. Rios. 2002. Selfing facilitates reproductive isolation among three sympatric species of Pitcairnia (Bromeliaceae). Plant Systematics and Evolution 232: 201-212.

Zapata, T. R. \& M. T. K. Arroyo. 1978. Plant reproductive ecology of a secondary decidous tropical forest in Venezuela. Biotropica 10: 221-230.

Received 9/2/2011; accepted 7/8/2011

Editor: Maria Cristina Gaglianone 